\title{
Umiędzynarodowianie szkolnictwa wyższego w Polsce
}

Umiędzynarodowianie szkolnictwa wyższego stało się dominującą tendencją w jego rozwoju w skali globu, swoistym megatrendem ${ }^{1}$, potwierdzeniem funkcjonowania cywilizacji wiedzy i edukacji. Powstaje globalna przestrzeń edukacyjna i badawcza, w której rywalizują nie tylko uniwersytety, ale i państwa, a jakość oferty dydaktycznej, umiejętność przyciągania zagranicznych studentów i wysoko wykwalifikowanej kadry naukowej, umiędzynarodowianie wyników prowadzonych badań naukowych i zaangażowanie w proces dydaktyczny na zagranicznych uczelniach stały się symbolami cywilizacyjnej atrakcyjności i nowoczesności ${ }^{2}$. Zmiany takie - z jednej strony - są szansą dla uczelni wyższych w Polsce na jakościową zmianę procesu kształcenia i powiązanych z nim badań naukowych. Z drugiej - są potężnym wyzwaniem wymagającym procesów adaptacyjnych uczelni w warunkach dopiero co kształtującej się w Polsce aktywniejszej polityki państwa w zakresie umiędzynarodowienia kształcenia i badań naukowych ${ }^{3}$. Tu bowiem Polsce właściwy jest syndrom „spóźnionego przybysza”, starającego się „nadgonić” stracony do tej pory czas.

Przedmiotem analizy w artykule jest - po pierwsze - proces umiędzynarodowiania kształcenia w skali globu jako rodzaj megatrendu, po drugie, umiędzynarodowianie w Polsce ze szczególnym uwzględnieniem kierunków „politologicznych” oraz - po trzecie - wielopoziomowo podejmowane w Polsce działania adaptacyjne do megatrendu umiędzynarodowiania.

1 Zob. J. Naisbitt, P. Aburdene, Megatrends 2000. Ten New Directions for the 1990's, New York 1990.

2 Zob. Strategia umiędzynarodowienia Wydziat Politologii UMCS w latach 20162021, Lublin 2016.

3 Zob. Program umiędzynarodowienia szkolnictwa wyższego, Ministerstwo Nauki i Szkolnictwa Wyższego, Warszawa 2015. 


\section{Tendencje globalne umiędzynarodowiania szkolnictwa wyższego}

Zakres przedmiotowy procesów umiędzynarodowiania szkolnictwa wyższego jest dość szeroki. Z jednej strony obejmuje procesy kształcenia, studiowanie poza granicami państwa pochodzenia, ale także wymianę nauczycieli akademickich czy zatrudnianie tych pochodzących $\mathrm{z}$ innych państw. Jest to udział nauczycieli akademickich w międzynarodowych konsorcjach dydaktycznych czy innych formach wspólnych, transgranicznych przedsięwzięć edukacyjnych. Z drugiej strony procesy te dotyczą badań naukowych, wymiany wiedzy i doświadczeń, funkcjonowania międzynarodowych zespołów i programów badawczych. Mając świadomość złożoności procesów umiędzynarodowiania szkolnictwa wyższego, przedmiotem dalszej analizy będzie dynamiczny, wręcz lawinowo narastający proces umiędzynarodowiania kształcenia rozumiany jako studiowanie poza granicami państwa pochodzenia studenta.

W roku 2015 w skali globu około 5 mln studentów studiowało poza granicami państwa pochodzenia ${ }^{4}$. Taka liczba jest skutkiem jej dynamicznego wzrostu w poprzedzających latach. W $1990 \mathrm{r}$. było to około 1,3 $\mathrm{mln}$ studentów, w 1995 - 1,7 mln, w 2000 - 2,1 mln, ale już w 2005 - $3 \mathrm{mln}$, w $2010-4,2 \mathrm{mln}$, a w $2012-4,5 \mathrm{mln}{ }^{5}$. Tendencją jest więc wyraźny wzrost liczby studiujących poza granicami własnych państw. Średnioroczne tempo przyrostu takich studentów w skali globu w ostatnich latach wynoszące 6\%, jest dwa razy wyższe od średniego tempa wzrostu ogólnej liczby studentów wynoszącego $3 \%{ }^{6}$. Szacuje się, że do 2025 r. liczba studentów zagranicznych w skali globu wzrośnie do około $8 \mathrm{mln}^{7}$. W porównaniu z rokiem 2010 oznaczałoby to wzrost o ponad 90\%.

Tak dynamiczny wzrost liczby studentów studiujących poza granicami państwa pochodzenia, a więc umiędzynarodowiania procesu kształcenia, jest efektem synergii kilku czynników. To one warunkują proces umiędzynarodowiania kształcenia i sprawiają, że staje się on megatrendem rozwoju

4 The state of international student mobility in 2015, http://monitor.icef.com/2015/11/ the-state-of-international-student-mobility-in-2015/ (dostęp: 24.02.2017).

5 Study in Poland. Studenci zagraniczni w Polsce 2016, Warszawa 2016, s. 8.

6 Ibidem.

7 A quick look at global mobility trends, http://classof2020.nl/wp-content/uploads/ 2015/02/Global-HE-Mobility-2015-Project-Atlas.pdf (dostęp: 24.02.2017). 
szkolnictwa wyższego. Po pierwsze, są to procesy globalizacji transportu i komunikacji, które warunkują kulturę mobilności ludzi, zwłaszcza młodych generacji, oraz kulturę otwartości na świat i jego różnorodność. Po drugie, umiędzynarodowianie rynku pracy w warunkach gospodarki opartej na wiedzy stymuluje do jej (wiedzy) zdobywania z jednoczesną mobilnością międzynarodową. Po trzecie, kształcenie stało się sektorem dynamicznie rozwijających się usług, źródłem dochodów uniwersytetów, ale i państw, czemu towarzyszy profesjonalizacja działań promocyjnych i organizacji procesu dydaktycznego. Po czwarte, wiedza naukowa i związana z nią jakość procesu kształcenia stały się elementem kształtowania atrakcyjności poszczególnych państw, swoistej ich soft power, budowania wizerunku nowoczesności i innowacyjności. Powstał więc rynek usług edukacyjnych z właściwym mu elementem rywalizacji o studenta zagranicznego uczelni, ale i państw coraz bardziej zaangażowanych we wspieranie umiędzynarodowiania oferty edukacyjnej ich uniwersytetów. Tym samym edukacja stała się nowym obszarem rywalizacji międzynarodowej z dążeniem niektórych państw do dominacji, swoistej mocarstwowości w tym zakresie. Jest to niejako „naturalne”. Funkcjonowanie bowiem w cywilizacji wiedzy i edukacji naturalnie" uruchamia rywalizację w tych dziedzinach i staje się elementem budowania pozytywnego wizerunku.

W 2014 r. największą była grupa studentów zagranicznych studiujących w Stanach Zjednoczonych - 974 926, co stanowiło 22\% ogólnej liczby studentów studiujących poza granicami własnych państw. W Wielkiej Brytanii studiowało 493570 studentów zagranicznych, co stanowiło 11\% ogólnej ich liczby. W Chinach 377054 i 8\%, w Niemczech - 301350 i 7\%, we Francji 298902 i 7\%, w Australii 269659 i 6\%, w Kanadzie 268659 i 6\%, a w Japonii 139185 i 3\%. W porównaniu z rokiem 2010 wymienione państwa - z wyjątkiem nieznacznego spadku o około 2 tys. - zwiększyły i to znacząco liczbę studentów zagranicznych. W Stanach Zjednoczonych o około 250 tys., w Wielkiej Brytanii o około 40 tys., w Chinach o około 112 tys., w Niemczech o około 55 tys., we Francji o około 21 tys., w Australii o około 39 tys., a w Kanadzie o około 95 tys.

Dominują więc wysoko rozwinięte państwa członkowskie OECD. Należy jednak zwrócić uwagę na fakt, że znaczące wyzwanie dla tej grupy państw tworzą Chiny. Do 2020 r. planują, aby liczba studentów zagranicznych przekroczyła 500 tys. Dla porównania w roku akademickim 2014/2015 w Polsce 
studiowało 46101 studentów zagranicznych, co stanowiło około 1,1\% ogólnej ich liczby w skali globu8 .

Skąd pochodzą studenci zagraniczni? W wynoszącej obecnie około 5 mln globalnej liczbie studentów zagranicznych ponad połowa, a dokładnie w 2014 r. 53,1\%, pochodziło z Azji. W największej liczbie są to Chińczycy, a następnie Hindusi i Koreańczycy z Korei Południowej. To właśnie w Azji mamy do czynienia z największą mobilnością młodych ludzi decydujących się na podejmowanie studiów poza granicami własnego państwa. Można więc mówić o bardzo wyraźnie ukształtowanym wśród młodych ludzi w znacznej części państw azjatyckich standardzie myślenia o ścieżce kariery zawodowej poprzez umiędzynarodowianie kształcenia i otwartość na wielokulturowość współczesnego świata. Tak ujęty standard myślenia rozwija się i w Europie, chociaż skala gotowości młodych ludzi do podejmowania studiów poza granicami własnego państwa w porównaniu $\mathrm{z}$ wieloma państwami azjatyckimi jest o ponad połowę mniejsza. W 2014 r. 24,6\% globalnej liczby studentów zagranicznych pochodziło z Europy. Z Afryki pochodziło 9,5\% studentów, z Ameryki Południowej i Środkowej 5,5\%, a Ameryki Północnej 3,5\%, a z Oceanii 0,6\%. Najwyraźniej młodzi ludzie ze Stanów Zjednoczonych i Kanady, ufni w jakość kształcenia na własnych uczelniach, wykazują niewielką gotowość do studiowania poza granicami własnych państw ${ }^{9}$.

Nieco inny obraz - niż ten ujmowany w liczbach bezwzględnych - przedstawia współczynnik umiędzynarodowiania kształcenia oznaczający udział studentów zagranicznych w ogólnej liczbie studentów studiujących w danym państwie. W 2014 r. na pierwszym miejscu była Nowa Zelandia, gdzie 18,74\% ogólnej liczby studentów stanowili ci zagraniczni. Następnie Australia - 18,30\%, Wielka Brytania 18,22\%, Szwajcaria 17,11\%, Austria 15,47\%, Belgia 11,19\%, Holandia 10,07\%, Dania 9,94\%, Kanada 9,72\%, a pierwszą dziesiątkę zamyka Finlandia z 7,43\% udziałem studentów zagranicznych. W rankingu tym Stany Zjednoczone są na 16. miejscu z procentowym udziałem studentów zagranicznych wynoszącym $4,21 \%$, zaś Niemcy na 11. miejscu z udziałem 7,23\%.

W rankingu określonym współczynnikiem umiędzynarodowiania studiów w poszczególnych państwach Polska jest na 24. miejscu z udziałem

8 Study in Poland. Studenci..., s. 10-12.

9 Ibidem, s. 11. 
1,97\%. Na tle innych państw Europy Środkowej i Wschodniej jest to dość znacząca różnica. Węgry są bowiem na 12 . miejscu z udziałem studentów zagranicznych wynoszącym 7,04\%, Słowacja na 15. miejscu z 5,62\%, Estonia 18. miejsce i 3,72\%, Litwa 21. miejsce i 3,04\%, a Słowenia na 22 . miejscu i 2,75\%. Polskę wyprzedziła Hiszpania, będąca na 23. miejscu z udziałem studentów zagranicznych wynoszącym 2,43\%. Z kolei Polska znacząco wyprzedziła Chile z udziałem $0,27 \%{ }^{10}$.

Korzyści z przyciągania studentów zagranicznych są jednoznacznie pozytywne, chociaż zróżnicowane. Po pierwsze, rywalizacja o studentów zagranicznych w powszechnej opinii przede wszystkim przyczynia się do podnoszenia jakości kształcenia na macierzystych uczelniach. Jego innowacyjności, zmiany koncepcji kształcenia na kierunkach jako całości, ale i w ramach poszczególnych przedmiotów, oferowania nowych, atrakcyjnych specjalności itd. Po drugie, korzyścią, doświadczaną w ostatnich latach szczególnie w Polsce, jest łagodzenie skutków niżu demograficznego. Po trzecie, jest to kształtowanie postaw otwartości polskich studentów na odmienności kulturowe współczesnego świata, postaw tolerancji i umiejętności funkcjonowania w środowisku wielokulturowym. Po czwarte, są to już wskazywane korzyści ekonomiczne. Wpływy finansowe warunkowane napływem do poszczególnych państw studentów zagranicznych w skali globu szacowane są na około 100 mld USD w skali roku, zaś w Polsce na około 150 mln USD. Nie należy zapominać o korzyściach dla środowisk lokalnych, budżetów miast, w których studiują studenci zagraniczni, ale także dla budżetów ich mieszkańców. Po piąte, jest to pozyskiwanie w absolwentach, którzy wracają do państw macierzystych, osób mających poczucie więzi z państwem, w którym studiowali, będących jego „ambasadorami”.

\section{Umiędzynarodowianie kształcenia w Polsce i specyfika „kierunków politologicznych”}

Niezależnie od dość odległych miejsc Polski w rankingach dotyczących umiędzynarodowiania kształcenia, mamy do czynienia z dynamicznym - zwłaszcza w ostatnich latach - wzrostem liczby studentów zagranicznych studiujących na polskich uczelniach. W roku akademickim 2015/2016 w Polsce

10 Ibidem, s. 9. 
studiowało 57119 studentów zagranicznych ze 157 państw. Rok wcześniej było to 46101 studentów, a w roku akademickim 2013/2014 - 35 983. W roku 2000/2001 liczba studentów zagranicznych na polskich uczelniach wynosiła 6563. Oznacza to, że w ciągu ostatnich 15 lat bez mała 9 razy wzrosła liczba obcokrajowców studiujących w Polsce. Wydaje się, że dla przyspieszenia dynamiki wzrostu liczby studentów zagranicznych istotne znaczenia miało członkostwo Polski w Unii Europejskiej. Tym samym dyplom uczelni wyższej w Polsce stał się jednocześnie dyplomem uczelni państwa członkowskiego UE. Wyraźną prawidłowością - jak do roku 2016 - jest, że wraz z upływem lat członkostwa Polski w UE wzrasta dynamika przyrostu studentów zagranicznych w Polsce w poszczególnych latach. O ile w roku akademickim 2005/2006 przyrost wyniósł około 1650 studentów, to między rokiem 2009/2010 i 2010/2011 około 4500 , między rokiem 2013/2014 i 2014/2015 było to 10 tys., a między rokiem 2014/2015 i 2015/2016 ponownie przyrost wyniósł 10 tys. ${ }^{11}$

Napływ studentów zagranicznych do Polski wyróżnia kilka cech specyficznych. Po pierwsze, jest to dominacja studentów z Ukrainy z wręcz lawinowo narastającą dynamiką przyrostu ich liczby. W roku akademickim 2005/2006, a więc w rok po uzyskaniu członkostwa w Unii Europejskiej, w Polsce studiowało 1989 studentów z Ukrainy. 5 lat później w roku akademickim 2010/2011 było to 4879 studentów, ale w roku 2012/2013 już 9747, w roku 2013/2014 - 15 123, w roku 2014/2015 - 23 392, a w roku 2015/2016 - 3058912. Oznacza to, że studenci z Ukrainy stanowią ponad 50\% ogółu studentów zagranicznych w Polsce. Używane jest nawet określenie „ukrainizacja” polskich uczelni wyższych.

W tym kontekście należy podkreślić, że w warunkach globalnej mobilności studentów dominacja w poszczególnych państwach jednej z grup etnicznych studentów nie jest czymś wyjątkowym. W 2014 r. w Stanach Zjednoczonych studiowało 303789 studentów z Chin, a na drugim miejscu byli studenci z Indii w liczbie 132 782, podobnie w Kanadzie studiowało 87329 studentów z Chin i 37399 studentów z Indii. W tym samym roku w Wielkiej Brytanii było 92915 studentów z Chin i na drugim miejscu 26975 studentów ze Stanów Zjednoczonych. W Niemczech w roku 2014 studiowały 33004 osoby z Turcji, 30511 studentów z Chin, a na trzecim miejscu 14525 studentów

11 Ibidem, s. 13.

12 Ibidem, s. 15. 
z Rosji. Z kolei w Chinach dominującą grupą byli studenci z Korei Południowej - 62 923, a na drugim miejscu studenci ze Stanów Zjednoczonych w liczbie 24 203. W Japonii dominowali studenci z Chin -77 792, a następnie studenci z Korei Południowej - $13940^{13}$. Na tle 30589 studentów z Ukrainy drugą co do wielkości grupą narodową w roku akademickim 2015/2016 byli studenci z Białorusi w liczbie 4615, a na trzecim miejscu z Norwegii - 1581, a następnie z Hiszpanii - 1407.

$\mathrm{Z}$ wyjątkiem proporcji między liczbą studentów z Chin i następnych co do wielkości studentów z Korei Południowej w Japonii, trudno doszukać się państwa, w którym mamy do czynienia $\mathrm{z}$ aż taką dominacją jednej grupy narodowej studentów zagranicznych, jak ma to miejsce w Polsce w odniesieniu do studentów z Ukrainy. Z jednej strony, tak liczna obecność studentów z Ukrainy na polskich uczelniach jest zjawiskiem pozytywnym $\mathrm{z}$ wielu powodów, wartością samą w sobie i potwierdzeniem dobrej reputacji polskich uczelni na obszarze poradzieckim, potwierdzeniem wartości wykształcenia uzyskanego w Polsce. Z drugiej jednak strony, pokazuje ograniczoną konkurencyjność oferty polskich uczelni w oczach studentów z innych państw niż Ukraina i Białoruś. To jednak jest wyzwaniem dla polskich uczelni, aby zwiększać napływ studentów $z$ innych kierunków geograficznych, przy jednoczesnym utrzymaniu tendencji napływu z obszaru poradzieckiego.

Po drugie, cechą umiędzynarodowienia kształcenia na uczelniach w Polsce jest relatywnie duża skuteczność uczelni prywatnych w pozyskiwaniu studentów zagranicznych. W roku akademickim 2015/2016 spośród ogólnej i już przytaczanej liczby 57119 studentów, 32277 studiowało na uczelniach publicznych, a 24842 na uczelniach niepublicznych. Są kierunki studiów, na których liczba studentów zagranicznych, należy domyślać się, że z Ukrainy, przewyższa liczbę studentów na tych kierunkach prowadzonych przez uczelnie publiczne. Do kierunków takich należy „zarządzanie”, ale i „stosunki międzynarodowe”, „ekonomia”, „informatyka”, „dziennikarstwo i komunikacja społeczna”. W roku akademickim 2015/2016 największa liczba studentów z Ukrainy studiowała na uczelniach prywatnych (Krakowska Akademia im. Andrzeja Frycza Modrzewskiego, Wyższa Szkoła Informatyki i Zarządzania w Rzeszowie, Akademia Finansów i Biznesu Vistula w Warszawie), a dopiero na 4. miejscu była pierwsza z uczelni publicznych, jaką jest UMCS w Lublinie. W roku tym

13 A quick look at global mobility trends... 
w rankingu 50 polskich uczelni z największą liczbą studentów zagranicznych, 30 to uczelnie publiczne, a 20 to uczelnie niepubliczne.

Po trzecie, wyróżnikiem napływu studentów zagranicznych do Polski jest znaczący, chociaż procentowo malejący, udział studentów mających tzw. polskie korzenie. Ogólna liczba tych studentów nieznacznie wzrasta. Jednakże ich procentowy udział w ogólnej liczbie studentów zagranicznych spada. W latach 2005/2006 studenci pochodzenia polskiego stanowili 36,9\% ogólnej liczby studentów zagranicznych, w latach 2010/2011 było to 19,2\%, w latach 2013/2014 - 15,6\%, a w latach 2015/2016 - 13,3\%. Tendencja ta - z jednej strony - wynika z ogólnego wzrostu studentów zagranicznych w Polsce, a z drugiej, że poczucie więzi z państwem ojców czy dziadków nie jest dominującym kryterium wyboru Polski jako miejsca studiowania.

Kierunki „politologiczne”, takie jak „politologia”, „stosunki międzynarodowe" $i$ „dziennikarstwo i komunikacja społeczna” należą do tych, cieszących się znaczącym zainteresowaniem studentów zagranicznych. W roku 2015/2016 największa liczba studentów zagranicznych studiowała na kierunku „zarządzanie”. Było to 6999 studentów, co stanowiło 12,3\% ogółu obcokrajowców. Na drugim miejscu był „kierunek lekarski” z 6275 studentami i 11,0\%, ale na trzecim miejscu „stosunki międzynarodowe” z liczbą 5030 studentów i 8,8\% udziału w ogólnej liczbie studentów zagranicznych. Na 10. miejscu znalazło się „dziennikarstwo i komunikacja społeczna" z liczbą 1381 studentów i 2,4\% udziałem, a na 12. miejscu „politologia” z liczbą 1025 studentów oraz 1,9\% udziałem ${ }^{14}$.

Studenci kierunku „stosunki międzynarodowe” w większości studiują na uczelniach niepublicznych. W roku akademickim 2015/2016 największa ich liczba (1000) studiowała na Krakowskiej Akademii im. Frycza Modrzewskiego, następnie na Uniwersytecie Ekonomicznym w Krakowie (uczelnia publiczna) - 529, ponownie uczelni niepublicznej, jaką jest Akademia Finansów i Biznesu Vistula w Warszawie - 497. Czwarte miejsce z liczbą 364 zajął Uniwersytet Warszawski, piąte Uczelnia Łazarskiego w Warszawie (334), szóste Wyższa Szkoła Menedżerska w Warszawie (301), siódme Collegium Civitas w Warszawie (246), ósme Uniwersytet Jagielloński (212), dziewiąte Uniwersytet Marii Curie-Skłodowskiej (175), a dziesiąte Uniwersytet Łódzki (172).

Studenci zagraniczni na kierunku „dziennikarstwo i komunikacja społeczna” także w większości studiują na uczelniach niepublicznych. W roku

14 Study in Poland. Studenci..., s. 20. 
2015/2016 największa ich liczba studiowała w Wyższej Szkole Informatyki i Zarządzania w Rzeszowie (181), a następnie w Krakowskiej Akademii im. Frycza Modrzewskiego (136). Dopiero na trzecim miejscu była pierwsza uczelnia publiczna - Uniwersytet Warszawski (112). Na czwartym miejscu była Społeczna Akademia Nauk (103), na piątym SWPS Uniwersytet Humanistycznospołeczny w Warszawie (98), na szóstym UMCS w Lublinie (91), na siódmym Uniwersytet Jagielloński (79), na ósmym Uniwersytet Wrocławski (65), na dziewiątym Akademia Finansów i Biznesu Vistula w Warszawie (64), a na dziesiątym Warszawska Wyższa Szkoła Humanistyczna im. Bolesława Prusa (63) ${ }^{15}$.

\section{Działania adaptacyjne w Polsce do procesów umiędzynarodowiania szkolnictwa wyższego}

Podejmowane w Polsce działania adaptacyjne do megatrendu umiędzynarodowiania szkolnictwa wyższego są dwupoziomowe. Z jednej strony podejmowane są na poziomie państwa, a z drugiej na poziomie poszczególnych uczelni, przy czy jeszcze do niedawna te drugie były dominującą tendencją. Oznaczała ona bierną rolę państwa w procesie umiędzynarodowiania szkolnictwa wyższego i konieczność polegania uczelni na własnych siłach, aktywności i kreatywności, czyli radzeniu sobie samym. Tendencja ta stopniowo jest zmieniana.

Istotnym elementem procesów adaptacyjnych w Polsce do megatrendu umiędzynarodowiania szkolnictwa wyższego jest ciągle powolny, ale postępujący wzrost aktywności państwa. Przejawia się on - z jednej strony - w opracowaniu strategii działań pod nazwą „Program umiędzynarodowienia szkolnictwa wyższego" przyjętej przez Ministerstwo Nauki i Szkolnictwa Wyższego latem 2015 r., a z drugiej, w tworzeniu struktur instytucjonalnych mających wspierać polskie uczelnie w procesie umiędzynarodowiania badań naukowych i kształcenia ${ }^{16}$.

W programie umiędzynarodowiania z 2015 r. dokonano dość krytycznej diagnozy dotychczasowych działań oraz określono zadania - z jednej strony - dla uczelni wyższych, a z drugiej, dla Ministerstwa nauki i Szkolnictwa Wyższego. Do jego głównych celów zaliczono: a) podnoszenie konkurencyjności polskich uczelni na rynku międzynarodowym, poprzez poprawę jakości

15 Ibidem, s. 25.

16 Zob. Program umiędzynarodowienia szkolnictwa... 
kształcenia i badań naukowych; b) zwiększenie udziału nauki i szkolnictwa wyższego we wzroście gospodarczym w Polsce; c) wzmacnianie pozycji Polski na arenie międzynarodowej przez wzrost jej atrakcyjności jako centrum rozwoju nauki i kształcenia.

Do celów szczegółowych zaliczono: a) zbudowanie wysokiej jakości - atrakcyjnych dla cudzoziemców - programów studiów I, II i III stopnia; b) podniesienie atrakcyjności polskiej oferty edukacyjnej poprzez międzynarodowe akredytacje; c) zawieranie międzyrządowych umów o współpracy, w tym porozumień o uznawaniu dyplomów; d) zwiększenie liczby wspólnych projektów edukacyjnych i naukowych realizowanych przez polskie uczelnie z zagranicznymi partnerami (w szczególności w ramach programu „Horyzont 2020”); e) włączenie studiów doktoranckich w system wymiany i współpracy międzynarodowej; f) zwiększenie liczby polskich studentów i absolwentów, mających za sobą okres nauki lub szkolenia na zagranicznych uczelniach; g) zwiększenie grona cudzoziemców studiujących na polskich uczelniach (zarówno realizujących pełen cykl kształcenia, jak i przyjeżdżających na wymianę); h) podnoszenie poziomu profesjonalizmu kadr akademickich przez postawienie odpowiednich wymagań w procedurach awansowych, większe zaangażowanie w badania prowadzone poza granicami kraju i z udziałem przedstawicieli szanowanych instytucji nauki, poszerzenie udziału recenzentów zagranicznych w ocenach dorobku; i) zwiększenie liczby zagranicznych profesorów wizytujących, przyjeżdżających z wiodących uczelni światowych; j) upowszechnianie katalogów dobrych praktyk wśród kadr akademickich, studentów i absolwentów polskich uczelni; k) usprawnienie i aktualizację systemu gromadzenia informacji o programach kształcenia, umowach międzynarodowych zawieranych przez uczelnie, o mobilności polskich studentów oraz o losach cudzoziemców absolwentów polskich uczelni i polskich absolwentach uczelni zagranicznych, o wybitnych Polakach, którzy uczestniczą w badaniach za granicą, a także o dostępnych stypendiach przyjazdowych i wyjazdowych; l) zbudowanie oferty stypendialnej poprzez uruchomienie programów mających przyciągnąć najlepszych studentów oraz laureatów międzynarodowych konkursów naukowych.

Dokonując krytycznej oceny dotychczasowych działań w zakresie umiędzynarodowiania szkolnictwa wyższego w Polsce, wskazano na czynniki ograniczające ten proces. Zaliczono do nich: a) niską pozycję uczelni 
w rankingach międzynarodowych, niską cytowalność dorobku naukowego polskich badaczy, ograniczoną liczbę publikacji w językach obcych, wydawanych w renomowanych czasopismach i wydawnictwach; b) umiarkowaną - z nielicznymi pozytywnymi wyjątkami - mobilność międzynarodową naukowców; c) niewielką liczbę programów kształcenia o najwyższym światowym poziomie, uznanych w międzynarodowych akredytacjach; d) niewielką liczbę programów nauczania prowadzonych w języku angielskim na studiach wszystkich stopni; e) zbyt małą liczbę wybitnych zagranicznych naukowców wykładających na polskich uczelniach; f) niewielką liczbę programów wspólnych prowadzonych z zagranicznymi partnerami; g) brak strategii umiędzynarodowienia przyjmowanych przez poszczególne uczelnie, niska świadomość potrzeby wymiany międzynarodowej u kadry akademickiej i administracyjnej oraz wynikająca stąd słabość obsługi studentów obcokrajowców i międzynarodowych programów badawczych; h) ograniczona wiedza cudzoziemców o dostępnych programach, stypendiach i możliwościach współpracy, a więc słabość działań promocyjnych; i) niskie wynagrodzenia kadry akademickiej w porównaniu z państwami najwyżej rozwiniętymi; j) niski poziom współpracy uczelni w realizacji planów umiędzynarodowienia.

Do czynników pozytywnych, sprzyjających umiędzynarodowianiu szkolnictwa wyższego w Polsce zaliczono: a) wzrost nakładów na infrastrukturę badawczą i dydaktyczną; b) rosnącą liczbę umów międzynarodowych, w tym dotyczących członkostwa Polski w dużych międzynarodowych organach badawczych; c) istnienie „wysp doskonałości”, zdobywanie renomy przez wiodące instytucje edukacyjne (uniwersytety medyczne, wydziały, których studenci zajmują czołowe lokaty w konkursach międzynarodowych, a uczeni zdobywają sławę odkrywców i prekursorów nowych badań), d) wzrastającą i monitorowaną jakość studiów; e) możliwość rozwijania dalszej kariery w Europie, w wiodących uczelniach i firmach świata lub ich lokalnych oddziałach w Polsce; f) liczną, rozproszoną w świecie diasporę polskich uczonych i studentów, z których część wyraża chęć współpracy z Polską bądź powrotu do polskich uczelni i instytutów; g) programy Ministerstwa Nauki i Szkolnictwa Wyższego i jego agencji wspierające zdobywanie przez studentów i badaczy nowych umiejętności oraz uczestnictwo w projektach lub konkursach międzynarodowych.

Do priorytetowych kierunków działań na poziomie uczelni zaliczono: po pierwsze, tworzenie atrakcyjnej dla cudzoziemców oferty kształcenia 
włącznie z: pozyskiwaniem akredytacji międzynarodowych, zwiększeniem liczby programów studiów I i II stopnia w językach obcych, oferowaniem programów studiów doktoranckich w językach obcych, zwiększaniem liczby zagranicznych nauczycieli zaangażowanych w proces dydaktyczny, zmianą systemu pracy uczelni, podnoszeniem kompetencji nauczycieli akademickich poprzez kontakty międzynarodowe, zwiększeniem liczby programów nauczanych $\mathrm{w}$ formie e-learning. Po drugie, podnoszenie kompetencji administracji uczelni w zakresie obsługi studentów zagranicznych. Po trzecie, tworzenie rozwiązań służących wspieraniu udziału nauczycieli akademickich w międzynarodowych programach badawczych. Po czwarte, wspieranie studentów i kadry naukowej w wyjazdach za granicę oraz powrotach do Polski.

Z kolei do priorytetowych zadań Ministerstwa Nauki i Szkolnictwa Wyższego w zakresie umiędzynarodowienia uczelni wyższych w Polsce zaliczono - po pierwsze - tworzenie oferty stypendialnej uwzględniającej priorytety programu, wspierającej zainteresowanie studentów zagranicznych studiowaniem w Polsce na wszystkich trzech stopniach, ale też zwiększającej możliwości polskich studentów podejmowania studiów na zagranicznych uczelniach. Po drugie, tworzenie warunków formalno-prawnych do wspierania międzynarodowej wymiany studentów. Po trzecie, stworzenie systemu monitorowania losów zagranicznych absolwentów polskich uczelni. Po czwarte, tworzenie baz danych na temat różnych elementów umiędzynarodowienia szkolnictwa wyższego w Polsce. Po piąte, stworzenie systemu wspierania zmian na polskich uczelniach sprzyjających procesom umiędzynarodowienia.

Istotnym elementem aktywnej roli państwa w procesach umiędzynarodowienia szkolnictwa wyższego w Polsce ma być utworzenie Narodowej Agencji Wymiany Akademickiej (NAWA). Ministerstwo Nauki i Szkolnictwa Wyższego przyjęło projekt ustawy, tworzącej podstawy utworzenia tej instytucji17. Rozpoczęcie jej działalności planowane jest od 1 października 2017 r. lub najpóźniej od 1 stycznia 2018 r. Do zadań NAWA ma należeć wspieranie uczelni w działaniach na rzecz umiędzynarodowienia kształcenia i badań naukowych, podnoszenie kompetencji ich administracji, stworzenie systemów stypendialnych wspierających wyjazdy polskich studentów i nauczycieli akademickich na zagraniczne uczelnie oraz przyjazdy zagranicznych studentów i nauczycieli akademickich na polskie uczelnie, stworzenie programu stypendialnego

17 „Gazeta Prawna”, 17.01.2017. 
wspierającego powroty polskich uczonych do Polski, rozwijanie działań promocyjnych na rzecz polskich uczelni ${ }^{18}$.

Istotnym uzupełnieniem tych działań jest tworzenie systemu informacji o możliwościach studiowania w Polsce. Rolę taką pełni portal internetowy „Study in Poland”. Znacząco przyczynia się on do wzrostu liczby studentów zagranicznych podejmujących studia w Polsce.

Procesy adaptacyjne podejmują poszczególne uczelnie, a nawet wydziały, zwiększając ofertę kształcenia w językach obcych bądź to w postaci programów w języku angielskim na poszczególnych kierunkach studiów, bądź to w postaci poszczególnych przedmiotów nauczanych w tym języku. Z drugiej strony, podejmowane są zmiany organizacyjne, dostosowujące uczelnie do wyzwań stwarzanych przez megatrend umiędzynarodowienia. W działania takie zaangażowany jest także Uniwersytet Marii Curie-Skłodowskiej w Lublinie, a w jego strukturze Wydział Politologii. Wydział ten jako jeden z pierwszych w Polsce w lipcu 2016 r. uchwałą Rady przyjął wydziałową strategię umiędzynarodowienia ${ }^{19}$. W dokumencie tym określone zostały obszary działania istotne dla umiędzynarodowienia kształcenia i badań Wydziału Politologii UMCS. Zaliczono do nich: a) tworzenie systemu zarządzania procesem umiędzynarodowienia; b) budowanie sieci partnerów zagranicznych; c) umiędzynarodowienie oferty dydaktycznej; d) zwiększenie mobilności studentów, nauczycieli akademickich i kadry obsługi administracyjnej; e) stworzenie warunków organizacyjnych dla procesu umiędzynarodowienia oraz określenie instrumentów jego finansowania. W Lublinie - obok działań władz UMCS - istotne wsparcie dla tego procesu tworzy zaangażowanie władz miasta, zwłaszcza w działania promocyjne, włącznie ze stroną internetową „Study in Lublin” 20.

Reasumując, należy podkreślić, że trwałą tendencją rozwoju szkolnictwa wyższego jest proces jego umiędzynarodowienia. Jest on swoistym megatrendem, zmieniającym szkolnictwo, wymuszającym procesy adaptacyjne. Proces ten w specyficznej postaci i w warunkach syndromu „spóźnionego przybysza”

18 Zob. Projekt ustawy o Narodowej Agencji Wymiany Akademickiej, https://bip. kprm.gov.pl/kpr/wykaz/r5860024574461,Projekt-ustawy-o-Narodowej-Agencji-Wymiany-Akademickiej.html (dostęp: 24.02.2017).

19 Zob. Strategia umiędzynarodowienia Wydział Politologii UMCS w latach 20162021, Lublin 2016.

20 Zob. Study in Lublin, http://www.studyinpoland.pl/en/index.php/news/36-study-in-lublin (dostęp: 24.02.2017). 
dotyka także uczelnie w Polsce, zmieniając je. Jeszce do niedawna były one pozostawione same sobie. Stopniowo zaczyna zaś wzrastać aktywna rola państwa. Oznacza ona uruchomienie adaptacji do procesów umiędzynarodowienia na poziomie państwa, ale również na poziomie poszczególnych uczelni i wydziałów.

\section{Bibliografia}

„Gazeta Prawna”, 17.01.2017.

Naisbitt J., Aburdene P., Megatrends 2000. Ten New Directions for the 1990's, New York 1990.

Program umiędzynarodowienia szkolnictwa wyższego, Ministerstwo Nauki i Szkolnictwa Wyższego, Warszawa 2015.

Projekt ustawy o Narodowej Agencji Wymiany Akademickiej, https://bip. kprm.gov.pl/kpr/wykaz/r5860024574461,Projekt-ustawy-o-Narodowej-Agencji-Wymiany-Akademickiej.html (dostęp: 24.02.2017).

A quick look at global mobility trends, http://classof2020.nl/wp-content/ uploads/2015/02/Global-HE-Mobility-2015-Project-Atlas.pdf (dostęp: 24.02.2017).

Strategia umiędzynarodowienia Wydział Politologii UMCS w latach 20162021, Lublin 2016.

The state of international student mobility in 2015, http://monitor.icef. com/2015/11/the-state-of-international-student-mobility-in-2015/ (dostęp: 24.02.2017).

Study in Lublin, http://www.studyinpoland.pl/en/index.php/news/36-study-in-lublin (dostęp: 24.02.2017).

Study in Poland. Studenci zagraniczni w Polsce 2016, Warszawa 2016.

\section{Streszczenie}

Celem artykułu jest ukazanie kategorii umiędzynarodowienia procesu kształcenia w skali globu jako rodzaj specyficznego megatrendu. Analizie poddana została skala internacjonalizacji we współczesnym szkolnictwie wyższym w kontekście przede wszystkim polskich doświadczeń. Szczególną uwagę Autor poświęca kierunkom politologicznym oraz wielopoziomowo podejmowanym działaniom adaptacyjnym w Polsce do umiędzynarodowienia. Autor 
zauważa, że trwałą tendencją rozwoju szkolnictwa wyższego jest proces jego umiędzynarodowienia. Jest on swoistym megatrendem, zmieniającym szkolnictwo, wymuszającym procesy adaptacyjne. Proces ten w specyficznej postaci i w warunkach syndromu „spóźnionego przybysza” dotyka także uczelnie w Polsce, zmieniając je.

Słowa kluczowe: umiędzynarodowienie kształcenia, szkolnictwo wyższe, internacjonalizacja nauki

\section{Abstract}

The aim of this article is to present the category of internationalization of the global education process as a specific megatrend. The analysis examined a scale of internationalization in contemporary higher education in the context of Polish experience. Particular attention is paid to the direction of political science and the adaptation activities taken on many levels in Poland leading to the megatrend of internationalization. The author notes that the stable trend in the development of higher education is the process of its internationalization. It is a kind of megatrend that transforms education and imposes adaptation. This process in its specific form and under the conditions of "the late newcomer" syndrome affects the universities in Poland and changes them.

Keywords: internationalization of education, higher education, internationalization of science 